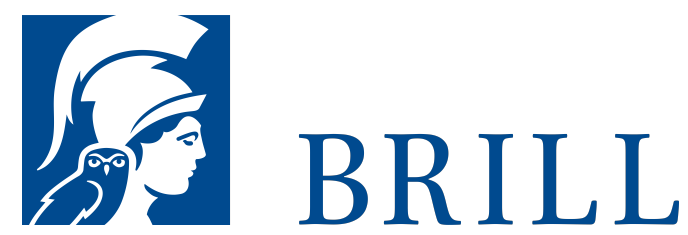

\title{
Ein Quäntchen Trost
}

Nachträge zur Glückseligkeit

Unter den knappen Gütern, um deren Ersetzbarkeit die Menschheit des 21. Jahrhunderts ringt, gehört der Trost zu den unersetzlichen. Darin gründet die Schwäche unserer Kultur, deren Technik, Humanität und Moral doch unübertroffen zu sein scheinen. Strassers Essay spannt den Problembogen vom klassischen »Trost der Philosophie« des Boethius bis zu Ian Flemings James Bond-Erzählung »Quantum of Solace«. Von der Metaphysik bis zur Psychologie reichen die rationalen Versuche, Tröstung zu »organisieren« im finsteren Tal, das wir alle durchwandern. Strasser zeigt, warum das psychologische Modell zu schwach ist. Es verharrt im Subjektiven. Und das Modell der Metaphysik? Dieses verblasst vor den Wissenschaften, die es selbst inthronisierte. Daher sucht der Essay nach Spuren einer »Geborgenheit im Schlechten« - einer objektiven Quelle des Trostes und der ihm eigenen Glückseligkeit.
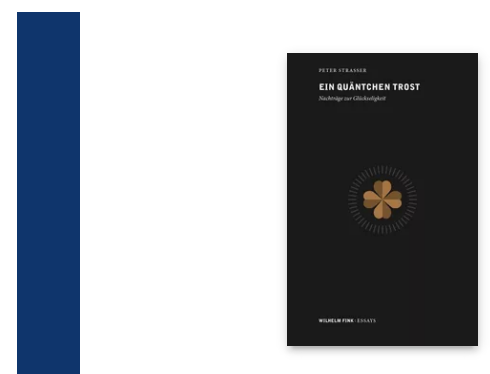

Pages: 135

Seiten

Language:

German

Subjects:

General,

Philosophy

Publisher: Brill |

Fink

Series:

Wilhelm Fink:

Essays

E-Book (PDF)

Released online:

10 Dec 2015

ISBN: 978-3-

8467-0002-O

List price

Paperback

Publication date:

23 Mar 2015

ISBN: 978-3-

7705-5843-8

List price 
Prof. Dr. Peter Strasser unterrichtet an der Karl-FranzensUniversität in Graz Philosophie und Rechtsphilosophie. Außerdem ist er seit 1999 Lektor und Gastprofessor am Institut für Philosophie der Universität Klagenfurt. Erhielt den Österreichischen Staatspreis für Kulturpublizistik 2014.

For more information see brill.com

\author{
Order information: Order online at brill.com \\ +44330 333 o049 | customerservices@brill.com \\ Submission information: brill.com/authors
}

Titles published by Brill | Fink, Brill | mentis or Brill | Schöningh: +49(o)71 5413279216 | brill@brocom.de 